\title{
THE LIFE CYCLE OF A TRAINING PROJECT IN A RESEARCH AND DEVELOPMENT UNIT
}

\author{
JOANNA Hess ${ }^{*}$ \\ *Center for Composite Technologies, Institute of Aviation, Al. Krakowska 110/114, 02-256 Warszawa \\ joanna.hess@ilot.edu.pl
}

\begin{abstract}
The article describes the life cycle of a training project in a research and development unit, from setting the training target, through analyzing the needs of the group, establishing workshops' programs and logistics, up to the evaluation and implementation support. The role of human capital has been presented in the article, thus the need for training organization has been demonstrated to improve quality of work. The article also describes characteristics of the training market, defining types of projects addressed to representatives of the most often trained groups in the research and development unit, like professionals, managers and research workers. Methods and tools aiding the training system analysis and monitoring have also been introduced in the text with a goal to reflect customer, employer, and trainee satisfaction. A process of raising qualifications of employees was described at the Institute of Aviation. It has been found that internal trainings from the subject matter of "project management" are the best solution for research and development centers.
\end{abstract}

Keywords: training, project life cycle, research and development unit.

\section{INTRODUCTION}

The principal objective of all training programs is to modify employee skills and attitudes. Training adapted to the needs of a research and development unit and its employees directly improves the competences of the trainees and the functioning of the whole company. All activities related to the preparation and the conducting of a training program are thus related to the concept of training project life cycle. Training is the most often chosen method of human capital development, despite its inconclusive impact on trainee development.

While preparing a training plan it is necessary to answer the question - is training the best method that positively impacts the functioning of the company by enriching it with needed competencies? A coherent training process begins by identifying needs, continues through plan execution, and ends on effect evaluation. 


\section{DEFINITION OF RESEARCH AND DEVELOPMENT UNITS}

Research and development units are, according to Polish law, primarily government owned organizational entities, separate legally, organizationally and financially, created with the objective of conducting scientific research and development works. They include [1]:

1. Research and development institutes

2. Research and development centers

3. Central laboratories

4. Other organizational units conducting research and development activities.

\section{THE TRAINING PROCESS}

Training is the planned and systematic process of change in employee behavior, allowing the gaining of knowledge, skills, and competencies required to the proper realization of tasks and to fulfill the personnel needs of research and development units [2]. The objective of training is the improvement of the performance of individual people, of groups of people, and of the whole organization [3].

A precise training project should include the following stages:

1. Analysis and identification of training needs (noticing the need for training and making the decision to satisfy that need).

2. Defining the objectives of training (formulating general goals which will allow the defining of specific goals).

3. Session planning (creation of a budget and timetable of the training sessions, selection of courses and of the locales where they will be held, creation of an annual training plan).

4. Execution of the training plan (running the training sessions, selection of specific training methods).

5. Control (evaluating training effectiveness).

6. Assessment of the training process (conclusions and for ex. planning the next training project)

The four final stages of the training project (planning, execution, control, and assessment) allow the proper conducting of training and form the so-called Deming cycle [4], or simply PDCA [4]. This is a model of continuous improvement introduced by William Deming $\{4\}$ in the 1930s. It describes a universal action model centered on quality in the organization and addresses the issues involved in the evaluation of training projects. The model suggests that qualitative evaluations should be made during the execution and influence the decisions of management and workshop leaders.

The Deming cycle has four stages [4]:

1. Plan - planning a better method;

2. Do - testing the plan;

3. Check - verifying if the new method indeed yields better results;

4. Act - applying the new method in the actual process.

\subsection{Analysis and identification of training needs}

The analysis and identification of training needs is the first and at the same time most crucial stage of the training project, since its skillful execution impacts the whole training process [5].

Certain assumptions, that are the essence of this stage, must be made. It is necessary to relate the needs of gaining knowledge of every member of the company with the capability of creating conditions of learning by the organization, and with the goals that can thus be attained. While defining goals one must take into consideration the needs of the most valuable resource - the human resource. 
The analysis of training needs is a meticulous review of defined training needs. Its main objective is finding ways to satisfy these needs. Numerous authors $[2,6 \div 10]$ distinguish three main areas of collecting information, which span the whole organization with all its elements (departments) and dependencies. These needs are on the level of $[2,6 \div 10]$ :

1. The organization

2. Employee teams (tasks)

3. Individuals

On the first and highest level is situated a review of the challenges faced by the organization, to whose resolution a training program or a professional development program could prove beneficial [11]. This analysis must take into account the current state of the organization, its level of development, as well as planned endeavors.

The priorities of the training project must be an integral part of the organization's development policy, otherwise they will not be effective.

The second level of analysis consists of systematic gathering of information on planned and possible tasks, which allows the defining of the competencies required to effectuate those tasks. The knowledge necessary for analysis at the level of the workplace is available through discussion between management and the employees, through company documentation, and through performance analysis.

The aim of training need analysis at the unit level is to determine the employees in need of training and their competencies that need developing. In order to achieve this, the level of the tasks performed by the employees is analyzed, and their opinions on learning needs are collected. Employees should collaborate with their direct superiors in determining their own training needs. Taking employee needs into account positively influences their motivation to learn, because a personal engagement in the training process is fundamental for effective learning. The employee should also identify with company needs, in order to perceive the benefits of training for the organization and for himself [7].

Stake-holder analysis is a very important part of the training project [12] [individuals or institutions that will be directly influenced by the project) as it supplies information on the reactions that can result to the actions taken during the training project. These stake-holder reactions can be positive or negative - disrupting the efficient execution of the undertaking. Stake-holder analysis can be considered a part of risk analysis. Stake-holder analysis is registered in a easy to read form that needs to be updated and to undergo subsequent analysis over the span of the training project. All the following stages of project development should refer to this form [12].

\subsection{Defining training objectives}

After defining training needs, it is necessary to proceed to the next stage, defining training objectives. The goal of this stage is to transform training needs into concrete objectives that translate into tasks. Determining training objectives has its advantages and its flaws, and very often the trainer puts these objectives above the expectations of the group, which leads to placing a quantitative evaluation above a qualitative evaluation. Such behavior often leads to unease on the part of the trained group [13]. It is essential to use the SMART (Simple, Measurable, Achievable, Rational, Timely defined) [14] rule when setting training objectives. This term concerns characteristics which should define a properly formulated objective. Using this method when setting objectives will allow, once training has been completed, to easily determine if a specific objective has been attained [15]. A precise definition of a high quality objective should fulfill five criteria:

1. Simple - the defined objective should be unambiguous and leave no room for free interpretation.

An example of an objective meeting this criterion is: the trainees will be able to efficiently use a new computer program. 
2. Measurable - the degree to which the objective has been achieved must be measurable. The objective must be measurable and expressed numerically. When it is not possible to define measurable criteria, unambiguous qualitative criteria must be found. An example of such a criterion could be: the trainees will gain knowledge on project management of projects financed for ex. by the National Center for Research and Development, the National Science Center, or UE grants. Once the training is complete, it is easy to verify if the employees effectively possess the knowledge related to this type of projects.

3. Achievable: defining the objective should take into account a realistic assessment of the situation (resources, advantages, risks, etc.). An unrealistic goal would be: the trainees will gain, over two days of training, an in depth knowledge of the production of composite structures used in aviation.

4. Rational - the objective should be coherent with the interests of the organization. For example a training course in auto-presentation will not benefit the organization if the trainees have no contact with customers.

5. Timely defined - objectives must have a date of completion, so that at every stage it is possible to verify if the project is on schedule to be completed. Training sessions should be conducted so that they fit within the time limits predetermined in the training project.

The principal goals, or the general objectives, are determined during the first stage. The second step is to define the specific objectives pertaining to competencies and knowledge to be gained by the trainees. The importance of each goal is determined in the next stage. The training firm must verify if these goals are attainable and eventually change them. The actions undertaken at this stage help avoid negative consequences further on. The result of this stage is the creation of a precise list of training objectives [13].

\subsection{Session planning}

Every project manager can have an individual system for planning training sessions. However, the best method is a timetable named after its creator - the Gantt chart [16]. The advantages of this tool are its clarity and its versatility. A Gantt chart can include everything that is necessary in a training project [16]:

1. Dates and times of training sessions and other events (meetings, tests, etc.);

2. Dates and times of payments, the project cash-flow;

3. The people participating in each training session.

The training timetable should above all include the names, dates, and venues of training sessions, as well as the names of employees partaking in them. The chart should include other elements such as: technological interruptions in the organization, holidays, marketing campaigns, etc. If such elements are omitted, it may later become necessary to modify the timetable and solve the occurring problems, such as setting new dates for the training sessions. The training process is subject to many changes, and the initial form of the project will not survive to its completion. It is necessary to follow rules that will allow the creation of a realistic training project timetable [17]:

1. All projects should be planned by several people.

2. The training timetable should be created in collaboration with the trainees or their immediate superiors.

3. It must be determined how many employees can be simultaneously taken off work for training.

4. Employees from departments with similar needs should be grouped together. Common problems and goals can be discussed in homogeneous groups.

5. Training people from different departments makes sense if their needs are comparable.

6. The employee's workload must be taken into account. They should be sent for training when it is the lightest. 
7. The number of training sessions per employee per year should be calculated.

8. Before planning courses, the time when the new skills will be put to use should be known.

\subsection{Implementation of the training plan}

The implementation of the training project should pass through the conducting of different types of training session (group workshops, mentoring, learning by working). Every course should take into account the needs and objectives of the company, as well as the capabilities and preferences of the employees. Group training is the preferred method for employees of research and development units. Typically they take place outside of company premises, in groups of 10-20 people. The larger the group, the more difficult it is to participate actively. The effectiveness of the training is enhanced by different methods used by the trainer that enhance trainee participation [17].

People learn in different ways. They collect data from the exterior world using all their senses (sight, hearing, touch, movement, taste). In every company there are individuals who have all the different styles of learning. Using the model proposed in the 1970s by David Kolb [18] allows employees with different styles of learning a chance to attain the training objectives. David A. Kolb [18] described the adult learning process, as a repeating cycle, where the starting point is an analysis of the person's experience.

David Kolb's process can be divided into four stages [18]:

1. Experience - the first stage, during which the participate assimilate knowledge by solving problems (in the domain of the skill that needs to be developed) using trial and error. The trainer focuses on past experiences and allows the gaining of new knowledge. His objective is to create particular situations and to propose exercises, which will allow the participants to draw conclusions and be convinced of the effectiveness of certain actions.

2. Reflection - during the second stage the trainer gives the trainees, through questions and discussion, the opportunity to reflect on what happened and why. This stage is very important as it allows the participants to share their impressions, and also - through reflection - to realize the effectiveness, the validity, and the purposefulness of the training.

3. Drawing conclusions - during the third stage experience and reflection are buttressed by theory. The goal of the trainer is to sum up the group's conclusions, supplement this with his knowledge of theory and his experience, and to help the participants to understand the observed phenomena.

4. Practice - during this last stage the trainer inspires and motivates the participants to apply their newly gained skills in practice. This stage consists of testing the new skills in practice. The participants test if they are able to use the new knowledge. Many people learn by doing, and profit most from sessions where they can use their gained skills themselves.

\subsection{Evaluation of training effects}

Training effectiveness evaluation is a necessary element of a systematic training model [19]. This concept must be understood as the systematic and complex gathering of information and a thorough assessment of all the components of an employee training system [20]. Effectiveness should be measured and analyzed at every stage of the implementation of the training course. Thus, this is a continuing and long-term process, and not only an ex post action.

Resources dedicated to employee training are an investment for the company. The assessment of training effectiveness is very important because it shows if the studied training program was effective in attaining the set goals, in what measure did it meet the expectations of the employees and of the organization, did the employees gain new knowledge and skills, and did the implemented change have a positive impact on company performance [21]. As a result the parties partaking in the training process [22] obtain complete feedback [23] in the form of an answer to the question whether the training program was only a cost for the organization, or was it an investment? 
The permanent effects of professional training can be observed only after a long time, and so they are difficult to quantify. Thus it is difficult to determine the degree to which the training influenced any positive effects that are observed in the long term. The positive changes could have been brought about by other factors (for ex. an expanding economy) influencing the company over time. In many cases it is necessary to accept both a quantitative and a qualitative evaluation. In this situation it is necessary to apply evaluation methods that give acceptable and comparable results [24] and to consistently measure basic conditions before training begins, in order to be able to measure the effectiveness of the use of company resources, which include: employees, equipment, finances, technology, etc. [25].

A good manager should evaluate the profitability of the investments in personnel that are made in his company. Up until several years ago this did not include training. Today, human resources managers are obliged to present a concrete evaluation consisting amongst others of quantifiable indicators of obtained economic results, including those being the result of training [17].

Conducting an evaluation of training gives many benefits, since employers gain information on the progress of the trained employees, and the trainees can verify the level of their acquired knowledge.

The valuation of training should answer the following questions [17]:

1. Were, and in what measure, the training objectives attained?

2. Do we know in what measure the participants' knowledge increased?

3. Were the knowledge and materials presented to the trainees appropriate to their needs?

4. Is, and in what measure, the obtained knowledge applied to the participants' work?

5. Was training profitable for the company? Would it be, perhaps less expensive to hire a new person already possessing the required skills?

The obtained results allow not only to evaluate the training project itself, but they also provide information on the processes that precede the training sessions: the conducted need evaluations, the definition of training objectives, training logistics. Training effectiveness evaluations can provide a wealth of information. A range of methods (tools) must be used in order to collect this information. Of these, the most commonly used are [15]:

1. Post-training questionnaire, studying the immediate reaction of the trainees;

2. Tests verifying their increase in knowledge;

3. Interviews with the trainees' superiors, concerning changes in attitudes and behavior during work;

4. Analysis of productivity;

5. Participation in a development center;

6. Effects in the form of concreate quantifiable results.

Different tools are used for different reasons. If we wish to assess the trainees' satisfaction, an interview is sufficient, while if we wish to study the change in their behavior after training, a "development center" method or direct observation in the workplace should be used [17].

Subject literature proposes a variety of models for conducting training assessments. The D.L. Kirpatrick model [26] was created in the 1960s and is considered today as one of the most useful and most often used ways of evaluating implemented training programs.

The model defines four levels of advantages on which effectiveness analyses are conducted [26]:

1. Reaction - here are collected the participants' opinions and level of satisfaction concerning the training's organization, the content, the methods used, and the possibility of applying the new knowledge in the workplace. The objective is to identify the factors that contribute to attaining the training's planned objectives. D.L. Kirkpatrick [26] calls this „customer satisfaction analysis”. This training assessment is made using a scored questionnaire. 
2. Teaching - analysis of the degree in which the didactic objectives of training were achieved, for ex. using tests. The objective is to compare the planned and the effective increase in qualifications after training. If the content of the training is completely new to the participants, a test should be made after the training sessions. If however the content is at least partially familiar to the trainees, a test should be applied before and after the training sessions.

3. Behavior - where it is determined to what degree the change in behavior in the workplace is the result of participation in the training program. Verification of how the knowledge, skills, and attitudes gained during training are applied by the trainees in his everyday work. Companies rarely use effectiveness analyses on this level because of the necessary expenditures in time and money.

4. Results - obtained by the participants of the training course and visible in the results of the whole organization. This analysis searches for data confirming the economic effectiveness of training in the form of indicators showing work efficiency, reduction of fluctuation, and reduction of costs. It is only several months after training ends that it is possible to evaluate its results.

In D.L. Kirkpatrick's method the levels of effectiveness analysis follow each other in a logical sequence [27]. For ex. participation in training boosts employees' enthusiasm for work, which leads to changes in their skills and attitudes, which leads to changes in behavior, which in turn are noticeable in the results obtained by the unit or the whole organization [28].

Research presented by A. Migowską and M. Woźny-Tomczak [29] indicates that research and development institutions in Poland usually only use the first level of the D.L. Kirkpatrick analysis method (77.6\% of respondents). Moreover, practically no other tools are used to study training effectiveness. The following levels of analysis are used only by a small group of companies. The "teaching" level is used by $28.6 \%$ of companies, while "behavior" analysis is used by $30.6 \%$ of companies. The last level of analysis is not used at all. What is interesting is that this last level of analysis allows the observation of indicators of training effectiveness, particularly in the long term [29].

A developed version of the Kirkpatrick model is the ROI model by Jack Philips [30], which allows the evaluation of the profitability of a training project. This model calculates two main indicators [30]:

1. ROI (Return on Investment) - net income of the investment / sum of costs incurred * $100 \%$

2. BCR (Benefits/Costs Ratio - Sum of income from the investment / sum of costs incurred

These indicators answer the question how much money the company will gain compared to the expenditures incurred by financing the training project.

Implementing Jack Philips ROI model, even to evaluate a single training project, can give a company very large, measurable benefits. This is of particular importance to people within the organization who are responsible for managing human resources, and who implement employee development projects. Since using the ROI methodology to evaluate training programs is a long and expensive process, it is not necessary to apply it to all training projects. Disposing of methods to calculate the return on investment of training programs allows the calculation of concrete profit from investing in human resources.

\subsection{Summary of the training process}

The summary of the training process is one of the most important stages since it provides information on what can be improved in the future. Creating a unified evaluation system for training programs is no simple task. The evaluation serves to find the strong and the weak points of training and to determine which employees gained the most and the least from the program. Not only does this assessment answer the question how similar training programs can be improved in the future, it 
also plays a motivating role to the trainees by providing them positive feedback regarding the results of the employee improvement process.

\section{WHY TRAINING IS IMPORTANT}

Training is necessary for companies in order to obtain qualified personnel and competitive advantage on the market, and for maintaining its market position [31]. For employees it is an opportunity to obtain knowledge, skills, and competencies necessary to fulfill their professional tasks, and to satisfy their employer's need for personnel. It is essential that employees dispose of the most current knowledge on the skills they possess, but also on the skills they wish to develop in view of their professional career. Participation in training should be related to financial benefits (higher salary), prestige benefits (promotion), or social benefits (networking, getting away from work) Some employees consider training to be a waste of time imposed upon them from above, and they participate in it with a negative attitude [32]. Modern employers perceive an employee's worth through the competencies he possesses. His attitude towards improving these skills is as important as his independent steering of his own professional improvement. The type of career chosen by an employee is dependent on his predispositions, and the opportunities and challenges he will face in the professional environment [33].

\section{TRAINING FOR EMPLOYEES OF RESEARCH AND DEVELOPMENT INSTITUTIONS}

When creating a company training plan, it is not advised to concentrate on specific, strategic from the company's point of view, homogenous groups of employees. Employees with varied profiles work in research and development institutions (scientists, technicians and assimilated, administrative and economic employees). In such institutions it is difficult to plan a training course for 10-20 people. Every employee in a research and development facility is usually working on distinct projects, has different training needs, and is confronted with problems and challenges specific to his area of expertise. A training project aimed at such a diversified group of specialists must include sending each specialist to a different open course, organized outside the company [34].

Designing a suitable improvement program for specialists in an institute is a serious challenge for the training project manager. The key to creating a training offer for specialist employees is finding common goals among their declared improvement needs.

There are several categories of training courses for such specialists. The first are training courses aimed at obtaining specific skills necessary to fulfill tasks in the workplace. Training courses of this type are most often held outside the company, in so-called open courses. The employee will have the opportunity to learn about a suitable subject, meet with representatives of other organizations, and exchange experiences with people from other industries.

With at least three employees needing similar specific training, it is profitable to organize a closed training course. The cost will be comparable to sending them to an open course. However, it will be possible to personalize the content of the course to the exact needs and expectations of the trainees. The offer of courses is very diversified, and there are many where a larger group of research and development institution employees can be sent. This type of training - for example in computer use, various certifications, use of new devices and machinery, etc. - is most often organized outside the company as an open course, or, in the case of specific requirements, as a closed course inside the organization [27].

The second group of training courses that can be aimed at a larger number of people in research and development institutions are "project management" courses. The Institute of Aviation runs many 
research and development projects financed by the European Union through structural funds, projects financed through government stipends or through grants from the National Center for Research and Development (NCBiR) and the National Science Center (NCN). Leaders of such projects must be trained in project management, for ex. risk analysis, so that they have the knowledge to correctly plan, implement, and control the tasks needed to attain their project's goals.

Internal training in research and development institutions, where the employees are trained by their superior or other employees, is most appropriate for "hard skills", for ex. the use of a new type of machine in the company, the implementation of new programs, technologies, etc. There are many specific posts and specific problems within institutes, and experts have the best knowledge of them. Organizing this type of wholly internal training courses allows for lowering costs in the long term.

\section{THE PROCESS OF EMPLOYEE QUALIFICATION IMPROVEMENT AT THE INSTITUTE OF AVIATION}

The basis for employee training at the Institute of Aviation is the training plan validated by the Director of the Institute of Aviation. The training plan is constructed by the department directors and the heads of all organizational units of the Institute, based on the training budget and on the needs resulting from planned tasks which require new skills or qualifications. The Human Resources training team is responsible for carrying out the training plan validated by the Director of the Institute of Aviation.

The training plan of the Institute of Aviation allows employees to cooperate with their superiors in steering their professional improvement and their career.

The first important phase in the life of a new Institute of Aviation employee is his familiarization with the organization and with his work post. On his first days in the new job the HR Director for Training provides him with a package of introductory training courses including workplace safety, fire protocols, quality systems, restricted materials system, the computer system. The objective of these training courses is to give employees a common base of knowledge about the Institute (how things work, company values), the preferred work methods, standard tools to use (computer systems, specialist documents), obligatory procedures, etc., and to increase the employees identification with the company. These courses are mandatory for all new employees and take place within the first few weeks of employment. Every new employee of the Institute of Aviation is also trained by his superior in the scope of his new work post.

Apart from the initial training courses, the Institute of Aviation provides foreign language courses as part of the employee improvement program. This includes technical language courses. Courses in English and in German are conducted by qualified Polish teachers and native speakers from an exterior firm.

The Institute of Aviation training plan also includes training pertaining to the development of interpersonal skills, so-called soft skills, which are aimed at developing universal skills that allow the efficient functioning of the individual and cooperation with other people. Courses aimed at managers, from whom solid theoretical knowledge and practical experience is required, are also provided.

All training courses, both those provided by external companies and those conducted internally, with the exception of the courses required by labor law, are evaluated. The effectiveness of training courses conducted externally by the Institute of Aviation is assessed via a questionnaire sent by email to the participants immediately after, and then again three months after the training is completed. Institute of Aviation employees are obligated to fill out and answer all the questions in the questionnaire. Both these completed questionnaires are sent to the employee's superior three months after the training is complete. This training assessment is very beneficial since the employer gains knowledge about the advances made by his newly trained employees, and the participants themselves verify the level of the knowledge they acquired. 


\section{CONCLUSIONS}

Independently from the form each training course takes, it is essential that it prepare the employees for a constantly evolving environment, that it engage them to finding new, effective solutions, and that it convince them that change will benefit everybody - the company, management, and each employee [35]. A review of the subject literature led us to draw the following conclusions:

1. Training projects must bring business benefits to the organization, and the training policy should support the company's objectives. The expectation of profitability should be the same for training as it is for any other type of investment;

2. Trainees and their immediate superiors should actively set goals and support the training process from beginning to end;

3. The most important objective of training is the application of the obtained knowledge in the workplace. In companies employing over 500 people, the main method of assessing the use of the effects of training in the workplace is informal feedback (58\%) [36], delivered directly, over the phone, and via email, during everyday contacts between employees and their superiors. Studies are much less popular $(20 \%)$, as are formal interviews and discussions $(13 \%)$, and detailed assessments (8\%) [36];

4. The evaluation of the effectiveness and efficiency of every training project is not an option, but a necessity. 39\% of Polish firms monitor the level of skills gained after training [37]. Only $37 \%$ of respondents analyze the use of trained skills in practice, and only $7 \%$ verify ROI profitability [37]. Studies show that in other countries the level of analysis of the effects of training is quite low as well. For ex. only $7 \%$ of U.S. firms measure the return on investment of training projects, and only $27 \%$ of companies in Great Britain use tests to measure what their employees learned during training [38].

5. The training project must take into account the needs of all company employees. In the European Union, two thirds of companies with more than 10 employees provide them with professional training. Unfortunately, in Poland, only $23 \%$ of firms train their employees. The leaders here are Austria and Sweden, where $87 \%$ of firms provide training [39]. In this category, Poland is outranked by countries such as Romania 924\%), Bulgaria (31\%), and Latvia (40\%) [39];

6. Training is change within the organization, and not the simple activity of trainers and the training department;

7. The expectation of profitability should be formulated towards training in the same manner as it is to any other investment;

8. Compared to other types of organizations (firms), it is more difficult to organize a training cycle in research and development institutions, aimed at larger groups of people, as the employees of this type of institution are very diversified.

\section{BIBLIOGRAPHY}

[1] Dziennik Ustaw z 2010r. Nr 96, poz. 615. (Ustawa z dnia 30 kwietnia 2010 r. o zasadach finansowania nauki).

[2] Armstrong, M., 2003, Zarzadzanie zasobami ludzkimi, Oficyna Ekonomiczna, Kraków.

[3] Bramley, P., 2001, Ocena efektywności szkoleń, Dom Wydawniczy ABC, Kraków.

[4] Hamrol, A., 2016, Zarządzanie jakością. Teoria i praktyka, Wydawnictwo Naukowe PWN, Warszawa.

[5] Kossowska, M. i Sołtysińska I., 2002, Szkolenia pracowników a rozwój organizacji, Oficyna Ekonomiczna, Kraków.

[6] Boydell, T. i Malcolm L., 2001, Identyfikacja potrzeb szkoleniowych, Oficyna Ekonomiczna Dom Wydawniczy ABC, Kraków. 
[7] Serafin, K., 2011, Identyfikacja potrzeb szkoleniowych, jako istotny obszar działań w zarządzaniu personelem, Problemy Zarządzania, 4/9/34, s. 191-203.

[8] Szałkowski, A., 2006, Podstawy zarządzania personelem, Wydawnictwo Akademii Ekonomicznej w Krakowie, Kraków.

[9] Rybak M., (red.), 2003, Kapitał ludzki a konkurencyjność przedsiębiorstw, Poltext, Warszawa.

[10] Król H. i Ludwiczyński A., 2006, Zarządzanie zasobami ludzkimi; tworzenie kapitału ludzkiego organizacji, Wydawnictwo Naukowe PWN, Warszawa.

[11] Bramley, P., 2001, Ocena efektywności szkoleń, Dom Wydawniczy ABC, Kraków.

[12] Bonikowska, M., 2006, Podręcznik zarządzania projektami miękkimi w kontekście Europejskiego Funduszu Społecznego, Ministerstwo Rozwoju Regionalnego, Warszawa.

[13] Kossakowska, M. i Sołtysińska I., 2006, Szkolenia pracowników a rozwój organizacji, Oficyna Ekonomiczna, Kraków, s. 269.

[14] Garski, K. i Gontarz, J., 2009, Jak efektywnie szkolić pracowników, wydanie I, Polska Agencja Rozwoju Przedsiębiorczości, Warszawa.

[15] Kopijer, P., 2011, Kompendium zarządzania szkoleniami, Wydawnictwo Szkoły Wyższej Psychologii Społecznej Academica, Warszawa.

[16] Bentley, T., 1994, Facilitation: Providing opportunities for learning, McGraw-Hill.

[17] Szczepanik, R. i Gancarz, B., 2008, Zarzadzanie projektem szkoleniowym, Wydawnictwo Helion, Gliwice.

[18] Kolb, D., 1976, The Learning Style Inventory: Technical Manual, McBer, Boston

[19] Janiak, I., 2001, Badanie efektywności szkoleń pracowniczych, Sukces w zarządzaniu, Problemy organizacyjno-zarzadcze i psychospołeczne, Wydawnictwo Akademii Ekonomicznej we Wrocławiu, Wrocław, s. 95.

[20] Pichnik-Kurdziel, A., 2000, Efektywność szkolenia zawodowego w teorii i praktyce zarzadzania personelem, Zeszyty Naukowe Akademii Ekonomicznej w Krakowie, 552, s. 44.

[21] Sajkiewicz, A., (red.), 2000, Zasoby ludzkie w firmie, Poltext, Warszawa.

[22] Griffin, W.R., 2004, Podstawy zarzadzania organizacjami, Wydawnictwo Naukowe PWN, Warszawa.

[23] Szałkowski, A., (red.), 2000, Wprowadzenie do zarzadzania personelem, Akademia Ekonomiczna Kraków, Kraków.

[24] Sidor-Rządkowska, M., 2001, Czy ilość przeszła, w jakość?, Personel, nr 19, s. 42.

[25] Janiak, I., 2002, Analiza kosztów i korzyści szkoleń, Personel, nr 5, s. 39.

[26] Kirkpatrick, D.L. i Kirkpatrick, J.D., 2009, Evaluating Training Programs, Berrett-Koehler Publishers, San Francisco.

[27] Pocztowski, A., 1999, Zarządzanie szkoleniami w firmie, Szkolenie i rozwój pracowników a sukces firmy, Wydanie I, Polska Fundacja Promocji Kadr, Warszawa, nr 1.

[28] Kunasz, M., 2008, Efektywność szkolenia i doskonalenia zawodowego - wybrane aspekty, Studia i Prace Wydziału Nauk Ekonomicznych i Zarządzania, 3, s. 129-141.

[29] Migowska, A. i Woźny-Tomczak, M., 2012, Jak ocenić efektywność szkoleń, http://hrstandard.pl/2012/10/01/jak-ocenic-efektywnosc-szkolenia/.

[30] Philips, J.J., 2010, ROI, czyli zwrot inwestycji w szkolenia i rozwój kadr, Wydawnictwo SWPS Academica, Warszawa.

[31] Aguinis, H. and Kraiger, K., 2009, Benefits of Training and Development for Individuals and Teams, Organizations and Society, Annual Review of Psychology, 60, pp. 451-474.

[32] Mathieu, J.E., Tannenbaum, S.I. and Salas, E., 2009, Influences of Individual and Situational Characteristics on Measures of Training Effectiveness, Academy of Management Journal, 4/35, pp. 828-847.

[33] Gunz, H.P. and Jalland, H.M., 1996, Managerial Careers and Business Strategies, Academy of Management Review, 3/21, pp. 718-756. 
[34] Rae, L., 2015, Planowanie i projektowanie szkoleń, Oficyna a Wolters Kluwer business, Warszawa.

[35] Szkutnicki, P., 2001, Przekonać załogę do zmian, Personel i Zarządzanie, 15/16/2001.

[36] ESI International, 2011, Applying Training and Transferring Learning in the Workplace: How to Turn Hope into Reality, www.esi-intl.co.uk.

[37] BPSC SA, 2016, Firmy nie analizuja efektów szkolenia, http://www.hrpolska.pl/newsy/hrkomentarz/firmy-nie-monitoruj-zwrotu-z-inwestycji-w-szkolenia.html.

[38] Andrzejczak, A., 2011, Wybrane dysfunkcje w dziedzinie zarządzania szkoleniami; Dysfunkcje i patologie w sferze zarządzania zasobami ludzkimi, Wydawnictwo Uniwersytetu Łódzkiego, Łódź, s. 153-163.

[39] http://stat.gov.pl/statystyka-miedzynarodowa/instytucjeorganizacje-miedzynarodowe/ess-eurostat.

\section{CYKL ŻYCIA PROJEKTU SZKOLENIOWEGO W JEDNOSTCE BADAWCZO-ROZWOJOWEJ}

\section{Streszczenie}

W artykule opisano cykl życia projektu szkoleniowego w jednostce badawczo-rozwojowej począwszy od wyznaczenia celów szkolenia, przez analizę potrzeb grupy, ustalenie programów warsztatów i ich logistyki, aż po ocenę i wsparcie wdrożenia. Zaprezentowano rolę kapitału ludzkiego i przez to wykazano potrzebę i istotę organizowania szkoleń, które mają na celu m.in. podniesienie, jakości wykonywanej pracy. Opisano charakterystykę rynku szkoleń określając rodzaje projektów adresowanych do przedstawicieli najczęściej szkolonych grup zawodowych w jednostce badawczorozwojowej: specjalistów, kierowników i pracowników naukowych. Przedstawiono metody i narzędzia pomocne $\mathrm{w}$ analizie i monitorowaniu systemów szkoleń uwzględniając głównie zadowolenie klienta: pracodawcy oraz szkolonego pracownika. Opisano proces podnoszenia kwalifikacji pracowników w Instytucie Lotnictwa. Stwierdzono, że dla jednostek badawczorozwojowych dobrym rozwiązaniem jest organizowanie szkoleń wewnętrznych, $\mathrm{z}$ tematyki „zarządzania projektami”.

Słowa kluczowe: szkolenie, cykl życia projektu, jednostka badawczo-rozwojowa. 